\title{
Photography as Jewish space
}

\author{
Michael Berkowitz \\ University College London \\ Revised 20 February 2015
}

Before the Nazi onslaught, photography was in large measure a Jewish space as a field of endeavour in Central Europe and beyond. ${ }^{1}$ Although a retrospective precise measure is impossible, it seems that there was as a greater level of participation of Jews in photography, compared to any other occupational or professional cohort (outside of the religious-Jewishspecific). There was a continuous flow of Hungarian Jews and Ostjuden in photographyrelated occupations into Germany and Austria, so making a clear separation between Central and Eastern Europe is difficult. ${ }^{2}$ In a narrow sense, calling photography 'Jewish' infers that in addition to photographers per se, studios, photographic laboratories, and photographic equipment stores tended to be owned by Jews. Jews also worked behind the scenes as retouchers and technicians in laboratories developing film, including medical and dental Xrays. They were prominent, and troubling to antisemites, as photography editors and agents. Erich Salomon (1886-1944) and Leo Rosenthal (1884-1969) were well-known Jewish press photographers who reached vast national and even international audiences. Jewish women such as Yva (Else Ernestine Neuländer [1900-1942]) and Ilse Bing (1899-1998) were among the most prolific advertising photographers. What might be termed the Jewish space of photography was thus expansive and diverse, comprising working space, living space, commercial premises where Jews interacted with non-Jews, outdoor and indoor public spaces where photographers conducted their work, and spaces of material culture such as billboards, newspapers, and magazines.

Most historiography that focuses on Central European Jewry, which has included a substantial photographic dimension, emphasizes one of two approaches: to show how Jews were represented, stressing their outsider or victim status, ${ }^{3}$ or to illustrate how Jews sought to 
represent themselves. ${ }^{4}$ With few exceptions, photography has not been acknowledged as a disproportionately Jewish economic realm. ${ }^{5}$ Scholars and curators have nevertheless excavated a notable Jewish presence, followed by an abrupt absence, in photography's history. But attention to the Jewish identities of the principals has been inconsistent. Jewishness often is reduced to a matter of origins, portrayed as significant only as the cause of persecution. Photographers themselves are most readily recalled in this context, while those who facilitated photography have been slower to attract notice. An immense amount of research remains to be undertaken, yet there is little doubt that Jews were conspicuous in establishing and working in studios and photo laboratories, devising and popularizing studio practices, advancing film and optical technologies, participating in empire- and state-building expeditions, photojournalism, advertising, fashion and sport photography, the retailing of cameras, film, and photo equipment, and the merging of photography into the fine arts, the avant-garde and socialpolitical movements. Much greater scholarly attention, however, has been paid to the picturing and representation of Jews 'as Jews' in inter-war Europe and to the Holocaust. ${ }^{6}$ A notable exception is the work of David Shneer on Soviet photojournalists, which brilliantly situates his subject on a larger historical field. ${ }^{7}$ Martin Deppner, through individual and collective projects, has been the most dedicated to discerning the myriad connections between photography's development and the involvement of Jews with the media. ${ }^{8}$ A great lacuna in contemporary history, generally, due to the Holocaust, is the very memory of the extent to which Jews predominated in continental European photography, which profoundly shaped photographic trends in Britain and the United States, ${ }^{9}$ and animated nearly every facet of the application and vocations of photography.

While it is indeed important to discuss those Jews involved in photography who were displaced, dispossessed, and murdered, such as photographers, picture editors, and proprietors of studios and photography stores, I wish in this chapter not only to recall or recognize Jewish roles or contributions in the pre-Nazi socio-economic order. In an approach consistent with a 
little-noticed article by Tim Gidal on Jews and photography in the 1987 Leo Baeck Yearbook, I wish to underscore the fact, which has received little recognition in the historiography of photography per se, that Jews were at the cutting edge of photography and changed the shape of mass visual culture ${ }^{10}$ It is not surprising, therefore, that a particularly treasured and memorable photograph of early post-World War II Germany_-for Germans and the world at large-was the work of a formerly German-Jewish photographer.

One of the more unusual books to appear in the aftermath of the Second World War is German Faces (1950), conceived by a Jewish refugee from Hitler's Germany, Henry Ries, and his non-Jewish, American-born wife, Ann Stringer. ${ }^{11}$ It was translated and republished in German around the time of the fall of the Berlin Wall. ${ }^{12}$ The first edition was not widely reviewed and elicited little scholarly interest. The blurb on its front cover reads: 'In magnificent photographs and text, a portrait of the people, large and small, leaders and led, who must remake Germany in their own image.' The text is one of the earliest surveys of postwar Germany to confront the fact that there was, in fact, a small Jewish minority living in the country, who faced unprecedented challenges. ${ }^{13}$ The book is distinctive for the way in which it called attention to the persistence of rabid nationalism and the feeling among many Germans that they were more victims than victimizers. ${ }^{14}$

Henry Ries, born as Heinz in 1917, would later be recognized for having brilliantly captured in an iconic photograph a signal historical moment: the Berlin airlift..' The few reviews of German Faces mention its portraiture as reminiscent of the work of August Sander (1876-1964) and note the overall quality of the pictures. ${ }^{16}$ In West Germany, Ries's photography became the subject of at least two exhibitions and another volume, ${ }^{17}$ and he published an autobiography in German. ${ }^{18}$ As well as acknowledging its artistic value, we might regard German Faces as significant in light of German-Jewish history and in relation to Jewish space. The book represents an attempt, however inadvertent, to reclaim photography in Central Europe as a Jewish domain. While Sander and some other leading (pre-Nazi era) 
photographers were not Jewish, the fact remains that Jews were tremendously overrepresented in photography, generally, before 1933. Helmut Gernsheim (1913-1995), himself a refugee from Nazi Germany, a superb photographer, and a foundational historian of photography, believed that there was a compelling Jewish story interwoven in the history of photography, although he never saw this idea through to completion. ${ }^{19}$ It is therefore neither an oddity nor coincidence that German Faces, a sympathetic collective portrait of the defeated nation, and Ries's scene of the Berlin airlift, one of the more moving images of Germans in the aftermath of the Second World War which 'reduced the tense showdown between the great powers to the image of children on a hillside watching a plane gliding in ${ }^{20}$, are the work of a Jewish photographer.

This said, I wish to defuse any impression that the current examination might be an exercise in valorization. Part of the reason why there is such a huge disparity between Jews' roles in photography and the notice they have received from non-Jews, and Jews, German and otherwise - is connected to the fact that for all the value placed on some photographs, photography itself was not considered the most respectable of vocations. ${ }^{32}$ Descendants of photographers are often unaware of their ancestors' profession. Historians had until quite recently barely begun to approach the problem of photographers' obscuration and marginalization. Photography's problematic relationship with respectability provided a critical opening for Jews, while it also helped obfuscate the Jewish inflection on the history of the field. Jewish and non-Jewish historians and theoreticians of photography have paid far too little heed to the social composition and commercial dimensions of the field. Meta-critiques of photography as racist, sexist, and beholden to dominant interests indicate a dearth of historical knowledge about its practitioners in general. The Polaroid company of Edwin Land (19091991), which was spectacularly successful at developing products for the United States military during the Second World War, was in 1944 derided and denounced for greed and 
disloyalty by the Boston Chamber of Commerce in terms that would have pleased the Nazis. ${ }^{33}$ Sir Kenneth Clark, who might have helped photography's institutionalization in the fine arts in Britain, withheld substantial support because he considered the leading expert on photographic history, Helmut Gernsheim, to be so 'unattractive'. ${ }^{34}$

Cultural attitudes, including derogatory stereotypes, influenced perceptions of the photographers' trade. Studio photographers were often regarded as less than dignified, and occasionally chided for their artistic aspirations. The production of photographs involved working long hours in darkness, with strange-smelling and hazardous chemicals; these unglamourous circumstances may have fuelled stereotyping. Early photography was sometimes seen as inextricable from pornography and unbridled egoism. The main function of studio photography, portraiture, often fostered an intimate relationship with the client. The photographer had to touch and position the sitter, which led to accusations that photographers took liberties. Furthermore, photographers were entrusted with retouching prints and negatives in order to please their customers. This dimension of photographers' craft has received little attention, in part due to persistent myths of the neutrality and honesty of photography. I. J. Singer's short story 'In der Finster' ('In the Dark') of 1919 reconstructs the dank, dark, and harried working world Singer experienced as a retoucher for Alter Kacyzne in Warsaw, ${ }^{35}$ where the photography trade was largely in Jewish hands. ${ }^{36}$ (Kacyzne suffered a horrific death at the hands of Ukrainian collaborators with the Nazis in $1941^{37}$ ) Israel Biderman ('Isiz', 1911-1980) drew an abrupt distinction between the servile character of retouching pictures according to customer demands, his first role in Paris after arriving from Marijampole, and the intrepid vocation of a 'true' photojournalist. His own transformation emerged, he said, in photographing his fellow partisans who helped liberate France from the Nazis. ${ }^{38}$

Moves towards acknowledging Jews' prominence in photography, especially in Germany and Austria, have been underway since the late 1950s. The rediscovery of Henry Ries in Berlin is a small part of this uncoordinated effort. A vast body of work exists, mostly in the 
form of exhibition catalogues on individual Jewish photographers — mainly those who escaped Nazi clutches and ended up in England, the United States, Australia, South Africa, South America, and Palestine. There are a few studies of those who worked as partners, and substantial volumes on notable photographers from Hamburg and Munich. ${ }^{40}$ Few scholars, though, have observed that beyond outstanding individuals, there were vital networks of Jews in photography that cut across generational and national lines. Rolf Sachsse has written of the multitude of photography studios in Germany in Jewish hands until 1933, and shown how 'Aryans' rushed to fill the roles vacated by Jews as agents and photojournalists. ${ }^{41}$ Christoph Kreutzmüller features two photographic institutions in his exhibition and catalogue Final Sale (2011), ${ }^{42}$ and his book Ausverkauf. Die Vernichtung der jüdischen Gewerbetätigkeit in Berlin 1930-1945, likewise acknowledges the significance of Jews in photography. ${ }^{43}$ In 2013 , an exhibition held at Vienna's Jewish Museum, 'Shooting Girls', focused on the women who owned and ran most of the 'quality' photographic studios in Vienna before the Anschluss. ${ }^{44}$ One of the curators confided to me that they began with a few and were quickly overwhelmed when the number grew beyond forty. The women of the "Shooting Girls" exhibition can be supplemented with a German cohort including Lore Krüger, Aenne Biermann, Yva, Lotte Jacobi, Gertrude Fehr, Ruth Jacobi, Ellen Auerbach, Ilse Bing, Grete Stern, Marianne Breslauer, Eva (Sandberg) Siao, Leni Sonnenfeld, Urusula Wolff-Schneider, Frieda Riess, Lore Lizbeth Waller, Yolla Niclas Sachs, Lisolette Grschebina, Lucia Moholy, and Gisele Freund.

In a recent article in German History, Annette Vonwickel argues that Jewish photojournalists fared unusually well as exiles due to the extensive professional networks they were able to exploit. ${ }^{45}$ While this is an important insight, she underestimates the cases of those who did not succeed in emigrating in the first instance, as well as those who fell under her radar because of having failed to reconstruct their careers. Vowinckel's piece, though, is significant because it is part of a larger effort in Germany to reimage Jews and photography 
and an unusually successful German-Jewish story. ${ }^{46}$

Perhaps most telling in terms of the extent to which photography had been a 'Jewish space' prior to 1933 is the fact that when the Nazis found non-Jewish photographers who were well established it was worthy of note. ${ }^{47}$ Although many Jewish photography businesses were ruined or taken over shortly after 1933, a number were allowed to remain open and particularly served Jews needing identification and passport photos. Some Jewish photographers, such as Erich Kastan, were able to work during Nazi times. ${ }^{48}$ This was due to the National Socialist penchant for documenting the Jewish cultural activities that were allowed, even officially encouraged. Some seventy individuals or families were explicitly assisted by Ernst Leitz and the famed Leica company based in Wetzlar. ${ }^{49}$ The Zeiss factories in Dresden and Berlin, like Leica, were reputed to be one of the least oppressive sites for Jewish forced labourers. But in 1939, a group of Zeiss employees took it upon themselves to persecute those who were still employed by the firm. ${ }^{50}$

, Harvey Fireside's description in an unpublished memoir of his family's business and their fate under the Nazis reflects the experience of a Viennese Jewish photography studio that was not among the 'quality' establishments previously mentioned. ${ }^{52}$ Since the Anschluss the business had been thriving, mainly due to Jews needing identity photos. During the event that came to be known as Reichskristallnacht, Harvey recalled that 'there was a loud rapping on the door. Two young men in brown Nazi uniforms stood on the threshold. They asked Father to put on his coat and accompany them. They were going to his photo store, not far away, in the Josefstadt, the eighth Bezirk (district) of the city. As the hours ticked by, I grew more and more anxious. First I had lost my mother; now I might become a true orphan., ${ }^{53}$ When Fireside's father 'finally turned up after eleven o'clock', his state did not provide much relief. $\mathrm{He}$

looked very shaken. His face was ashen, and his hand trembled when he tried to light a 
cigarette. He told us that the pair of Hitler Youth had made him unlock the store, then they had pulled down the Rollbalken [metal shutters]. It occurred to him that they might kill him without any witnesses being able to peer in from the street. Gradually, however, it dawned on him that they were merely bent on plundering as much as they could. Cameras, accessories, photo albums, even light furniture was jammed into the sidecars of motorcycles they had parked at the kerb. Father lapsed into his sales pitch to stall for time. He showed the men how these gadgets worked: the flash units, light meters, the newest imported

equipment. ... Finally there was a commanding rap on the shutters. When the Hitler Youth looked outside, they found someone who outranked them: an older man in a black SS uniform. What were they doing there, he demanded. 'Wir nehmen nur, was uns gehört' [we're only taking what belongs to us], they answered. But the SS man wasn't satisfied. He asked for their paper(s) to prove they were taking the loot to a designated warehouse, not just indulging in ad hoc plunder. They conceded that they had been in such a rush to engage in the Judenaktion [the anti-Jewish measure], they had not bothered with formalities. The SS man told them to leave the place. He would take over, seal everything up, and decide what was to be done with the Jew. ... Father ...

thanked the SS man, whom he recognized as Gerd Kalmus, an old customer, for probably saving his life. 'Don't bother', was Gerd's reply, 'just go home and pack up - there's no future for you here in Vienna.' ... We would need another year and a half to obtain the myriad permits required to leave the country and have them coincide with the most precious paper of all: a visa from the United States. ${ }^{54}$ 
In addition to the Shooting Girls show, memoirs such as Fireside's, and related artefacts, there is another formidable source of data about Jewish and photography in Vienna: the records of the Mauthausen concentration camp. Located nearer to Linz, the infamous granite quarry which was the centre of the labour camp belonged to the city of Vienna. Close to 200,000 prisoners went through the Mauthausen camp system between August 1938 and May 1945. ${ }^{55}$ Some 95,000 died there, among whom at least 14,000 were Jews. Records reveal that at least 125 of these Jews were photographers or worked in studios or laboratories. ${ }^{56}$ I would estimate that there might have been between two and four hundred Jewish photographers who died in, or passed through the camp, given the sketchiness of information during different periods, and the tendency for inmates to list occupations that they believed might facilitate survival. Many of those declared as photographers were Hungarians who had come through Budapest or elsewhere in Hungary, while others were from Poland. ${ }^{57}$

One of Mauthausen's Jewish photographers was Bernard Gotfryd. ${ }^{58}$ Interestingly, Gotfryd did not claim photography as his profession on entry to the camp. He chose instead to call himself a locksmith, because he had heard that this was one of the preferred vocations for work details and therefore a possible factor in life or death. ${ }^{59}$ Gotfryd is well published, but his writing and life story have been underused and perhaps undervalued by scholars. ${ }^{60}$ Scant attention has been paid to his work with regard to photography and the Second World War, which he describes in meticulous detail. Soon after the outbreak of war, he, as he explains, 'was hired as an apprentice at a photography studio owned by a friend of the family. (There were no more schools for Jews) ${ }^{62}$ He worked there until August 1942 and then got a position in remaining studio 'owned by a Polish couple of German descent [who] were given permission by the Polizeiführer to employ three Jews'. ${ }^{63}$ Some aspects of Gotfryd's work as a photographer in the Radom ghetto were of particular note. First, he photographed Jews and non-Jews, and even Nazi officers, in the studio. ${ }^{64}$ Indeed, it was very popular with the soldiers, and they also used it to have film developed of the pictures they took of their comrades - 
typical tourist shots and battlefield scenes - as well as images of grotesque treatment of civilians. $^{65}$

Gotfryd was approached by Alexandra, a non-Jewish woman in the Polish underground, who asked Gotfryd to undertake the dangerous assignment of making duplicate negatives of photographs revealing the brutal nature of the occupation, 'atrocities and executions', so that these could be used to prove the Poles' case of what the Nazis were inflicting on their country. The underground also was keen to have portraits of 'high ranking officials of the Gestapo' and SS men, many of whom ignored explicit orders not to have themselves photographed in commercial studios. ${ }^{66}$

In the context of the Holocaust, Gotfryd's relations with the Nazis might seem strange. He was, in many respects, treated 'normally', perhaps because he was helping to provide a service that was appreciated. Gotfryd had an unusually close relationship with a Waffen SS-man he referred to as 'Kurt', who supplied him with bread and extra food. ${ }^{67}$ At their second meeting, Gotfryd recalls that "we had a fairly long conversation about camera techniques and films, but he volunteered nothing about himself. He liked to take pictures of landscapes, he told me, but still had difficulties getting the right exposures. Then he asked me all about life in the ghetto, and about my family. "One day when the war is over," Kurt said, "we'll have a long talk. Now it may be dangerous."' Kurt helped him to obtain medication for his grandmother without taking anything in return. 'Soon after, Kurt brought a picture of his own grandmother into the studio and ordered a copy of it for his wallet. Many German soldiers would bring in their old family photos to be copied so they could carry them in their wallets. Looking at the picture after he had gone, I realized that there was nothing typically Germanic about his grandmother; for one reason or another I made an extra print of it and took it home to show to my parents. ${ }^{68}$

Godfrey also tells a story about how the photographer Orenstein, his wife and son were saved by a Nazi, sent into hiding during a round-up for transports. Gotfryd was witness to this scene: 
On a beautiful Sunday afternoon in August 1942 a heavy-set man dressed in a Gestapo uniform, fully armed and wearing a steel helmet, left the Radom ghetto escorting a man and a woman and a sickly-looking little boy. ... [The Gestapo man's] name was Helmut Reiner.

His expression was extremely serious, as

if he was trying to add an air of formality to his mission. Heavy beads of perspiration rolled down his face onto his neck, dripping under the collar of his woollen tunic. Clearly he hadn't thought to loosen the collar; to do so would be against regulations. ${ }^{69}$

\section{Reiner, Gotfryd informs us,} was the photographer at the Gestapo headquarters, and Orenstein, a master in his art, was his negative retoucher. High-ranking Gestapo officials were not to be photographed in privately-owned studios; photography at Gestapo headquarters became solely Reiner's responsibility. As soon as Reiner had heard about the upcoming deportations in the ghetto he decided to keep Orenstein out of it. He had known him for over a year; he respected him for his superb craftsmanship and punctuality. Reiner knew that he was taking a chance protecting a Jew, but he was willing to do it; it wasn't in his nature to turn his back on people in need of help, particularly an esteemed friend. .... When in

Vienna on furlough he had even told his wife what a decent couple the Orensteins were and how badly off the Polish Jews were; she had approved of his helping them. ${ }^{70}$

Yet there was also a pragmatic dimension. 'Reiner wanted to stay in Poland as long as he possibly could. Things weren't too bad for him there. If he could only have Orenstein, his photography operation at the Gestapo might be assured, and he might not have to go to the east. ${ }^{, 71}$ The plan worked: 'For almost another year Orenstein was employed by Reiner, retouching the Gestapo negatives. Occasionally Reiner would visit him in the ghetto, bringing him extra food. Late in 1943 the last of the [Radom] ghetto was liquidated, and the Orensteins 
were shipped to camps. ${ }^{72}$ Orenstein, a diabetic, was sent home to Vienna, where he stayed until the end of the war. The Orensteins survived the camps, but their son did not.

Although Godfryd does not know for certain, it seems that Reiner had apparently worked as a photographer in Vienna before the Anschluss and was not enamoured of antiemitism. ${ }^{73}$ It is likely that he was comfortable with Jews. Departing from Gotfryd's observations, we might delve more deeply into Reiner's sympathy for Orenstein. Why would a retoucher in the Gestapo photo studio be so important? The Nazis found that relatively objective professional and forensic photographs did not necessarily tell the kind of the story they desired. For instance, Nazi press organs avoided using photos of Jews who did not seem to 'look Jewish' ${ }^{74}$ The Nazis needed an expert retoucher for SS photographs for similar reasons: a lot of the supposed Nazi racial elite had rather big noses and large ears and were not particularly attractive, and at the very least needed making more presentable and more stereotypically 'Aryan' in photographs. ${ }^{75}$ Besides the value of a retoucher, there are other reasons why Gotfryd and Orenstein may have been treated rather humanely in the context of the Holocaust. At the heart of this lies the notion of photography as a Jewish space: Even the Nazis regarded it as normal, and desirable, to have Jews taking care of photography, except for enclaves such as the Erkennungsdienst at Auschwitz and other camps. ${ }^{76}$

Before coming to power, Nazis were apparently not averse to using the services of a Jew when in need of a professional quality photograph. It is reputed that Lotte Jacobi was offered 'honorary Aryan status' by the Nazis in 1935 because her clients included 'high-ranking German officials' who 'praised her work as "good examples of Aryan photography”. This may seem ironic, as Lotte and her family were said to be politically active on the left. ${ }^{77}$ Jacobi herself, however, never claimed to have participated in 'political activities' or 'social causes' beyond conversation. Moreover, she adamantly denied that her work had 'political content': 'I photographed the politicians of all parties,' she asserted. 'I didn't select one over the other. ${ }^{, 78}$ Jacobi's comments remind us that Jews in photography did not mainly take pictures of Jews, 
or those they considered sympathetic, but of everybody, including those they might have considered unseemly or who espoused ideologies from which they themselves were excluded.

However, being permitted as a Jew to work under the Nazis as a photographer did not mean that one's life would be spared. The famed Yva, Else Ernestine Neulander, who had been one of the great advertising and fashion photographers of Central Europe, continued a career in photography of sorts as an X-ray technician in Berlin's Jewish hospital until 1942, when she was deported to her death at Sobibor. ${ }^{79}$ One of the most illustrious Holocaust victims was a fellow photographer, Erich Salomon, who is widely credited with establishing enduring trends in photojournalism. Salomon's work was characterized by a combination of impeccable timing and the deft concealment of himself and his camera. He also evinced a distinctly modernist gaze, as in photos shot through car windows, and from across a dark street into a building. Salomon's impact was particularly promoted by Stefan Lorant, who became a leading editor of the pictorial press in Britain after his imprisonment by Hitler and escape from Munich. Lorant and his British publications, in turn, played a huge role in shaping the character of Life magazine, as did the émigrés on its staff and among its leading contributors, such as Fritz Goro, Alfred Eisenstaedt, and Robert Capa, and its founder Henry Luce's exposure to the work of Stefan Lorant. ${ }^{80}$

At the time of his death in 1969, Leo Rosenthal was well-known and respected, mainly as a photographer at the United Nations, and received a substantial obituary in the New York Times $^{81}$ whose author was apparently unaware that Rosenthal had been a distinguished photographer in Germany before his arrest by the Nazis in 1933. Rosenthal's trove of photographs provided the basis for an exhibition at the Berlin Landesarchiv (November 2009 to March 2010) and an accompanying catalogue. ${ }^{82}$

Rosenthal was born in Riga, then in tsarist Russia. He was no traditional, poor Ostjude; his father was a well-established jeweller to the city's elite. ${ }^{83}$ Leo Rosenthal initially became a lawyer, practising in Moscow and engaged in revolutionary politics. Although his sympathies 
were on the side of the Reds, he did not believe he would fare well enough under the Bolsheviks and subsequently moved to Berlin, becoming a reporter for socialist and 'liberaldemocratic' newspapers, mainly Vorwärts. His photographs also appeared in the 8 UhrAbendblatt, the Weltspiegel, the supplements to the Berliner Tageblatt and Vossische Zeitung, the illustrated Zeitbilder, and the Volksfunk. He struggled to make a decent livelihood out of his assignments; his living conditions and economically precarious existence, especially in comparison to his opulent family home, were disheartening. In Germany he was a Social Democrat but remained on its 'periphery'. ${ }^{84}$

Not surprisingly, Rosenthal was prominent enough to find himself taken into 'protective custody' upon the Nazi takeover of power. His Latvian citizenship facilitated his release from prison in Berlin. ${ }^{85}$ He escaped first to his family's home in Riga, where he participated in a largely Jewish anti-Nazi German publication, then on to the west, via Paris and Casablanca. ${ }^{86}$ His mother, brother, and three sisters were not so fortunate; all were murdered in the Holocaust. Rosenthal arrived in the United States in 1942. The launch in 1945 of the United Nations with its conference in San Francisco saw him seize the opportunity to return to photography as his main vocation.

The Berlin exhibition and volume referred to above concerns Rosenthal's work from a circumscribed period, 1926-1933, and principally details his engagement with the legal environment on which he reported. Although the essays discuss Rosenthal's development as a photographer per se, and include several comparisons with his better-known colleague, Erich Salomon, they reveal a blind spot about the prevalence of Jews in photography. In contrast, the importance of Jewish connections is presented well in Bianca Welzing-Bräutigam’s examination of Rosenthal's period in Riga and peripatetic existence after fleeing the Nazis. ${ }^{89}$ Erich Salomon was not simply a contemporary and forerunner to Rosenthal: his emergence was due to his situation in a disproportionately Jewish milieu, including agents, editors, picture editors, publishers, and agency heads. Those who are familiar with Salomon would 
rarely mistake his photographs for those of Rosenthal. Even though Rosenthal took many, if not most of his courtroom photographs surreptitiously - as did Salomon - there is more of a formal, staged, static quality to them, with some exceptions. ${ }^{90}$ Most of his shots are of people while they are relatively still. Salomon, by contrast, often caught people in motion. Rosenthal's photos are competent, 'stimulating' and 'realistic', ${ }^{91}$ relatively well-composed, but not terribly interesting if not for the subject matter. Rosenthal was at the cutting edge politically, in terms of what he was exposing, but as a photographer he was not avant-garde in terms of technique. He was, in this respect, more like his British counterpart James Jarché, rather than Salomon, Alfred Eisenstadt, and Robert Capa. ${ }^{92}$ His work does not reflect the transition to motion picture film, as did that of others in his loose cohort.

While it is important to focus on Germany and Austria and the dispersion of its émigrés in relation to this field, it is also appropriate to mention lands on which the Nazis imposed themselves. Perhaps the only countries where Jews in photography were not vastly disproportionate to their numbers in the general population were Belgium and Estonia. The figure in France was relatively low, at some ten to fifteen percent, but still significant. Most other countries seemed to have percentages of 30 to 40 percent or greater. We should not neglect in this context to draw attention to Jewish photographers in the countries where Jews were largely obliterated. In Lithuania, to cite one example, 94 to 95 percent of the Jews were murdered, mainly by the Einstazgruppen, in sites such as the Ninth Fort and pits of Ponar. An attempt to reconstruct and interpret what Jews did in their daily lives in Eastern Europe reveals that photography played a highly significant part in Jewish existence. In Kovno, for instance, there were photography shops throughout the city centre, of which perhaps not a single one was owned by a non-Jew.

One reason for including Lithuania in this chapter stems from the phenomenon of the transcendence of conventional boundaries in favour of elective affinities. Jews in photography, throughout Lithuania, were comfortable in the both the German culture to the 
west and the Russian to the east. Therefore, in the early twentieth century and through the interwar years, we often see today's city of Kaunas presented neither as Kaunas, nor Kauen, but as 'Kowno'. While by no means 'German Jews', Lithuanian Jews' ties to German culture and language were not as tenuous as it might seem. I In the western parts of Lithuania in particular, Jews had been part of a German cultural universe, while also being Lithuanian, Polish, and Russian.

There has been at least one attempt to recover the history of a Jewish photographer from Samogitia, the western region of Lithuania near Memel, one Chaimas Kaplanskis, or Chaim Kaplan, through an exhibition and catalogue (2007). ${ }^{93}$ Chaimas Kaplanskis has been referred to as 'the best known photographer of Telsiai [Telz]'; the family's professional photographs 'reflected the cultural and public life of Western Lithuania at that time', and it is claimed that Feitska Kaplan was 'the first female photographer in Telsiai and one of the first in Lithuania. The Kaplanskis' photo studio ... was open for half a century and owned by the family itself for 47 years (1894-1940) ... Even today in almost every house of Telsiai one can find at least one photo made in the Kaplanskis' photo studio., 94

Compared to so much on photography that is theoretically oriented, this is a modest project. Its main purpose is to illuminate the history of Samogitia, a region which prides itself on having a distinct cultural heritage. It also speaks volumes about the relationship of Jews to photography. Photography in Telsiai was initiated in 1860 by Chaim Arenson and was well established in every Lithuanian city, and even many towns and villages - mainly by Jews by 1870 .

A large share of the text details how the collection came to be discovered and how the exhibition materialized. Perhaps the most important message to be gleaned from this catalogue, however, is that Jews did not exist in a totally separate sphere from Lithuanian nonJews. Although no one has gone so far as to assert that there was ever something akin to the 'German-Jewish dialogue', there were striking points of cordial contact, it seems, between 
Jews and non-Jews in Lithuania. Photography was an area in which Jews and non-Jews came together with little tension. Chaimas Kaplanskis was regarded as the premier photographer of Telsiai by the entire population, as his clients included prominent priests as well as rabbis, and he made portraits of Catholic seminary students as well as yeshiva bokhers. We also learn, however, that Jewish photographers were among those who suffered discrimination as the notion that non-Jewish Lithuanians needed to wrest business from so-called 'foreign' hands gained ground in the 1930s. ${ }^{95}$ Many lost their livelihoods even before 1939, owing not to market forces but to ethnic-national conflict.

Interestingly, the tribute to the Kaplanskis is not cast as a Holocaust history, nor should it have been. Of the three children who followed Chaimas into the photography business, the two boys emigrated to Palestine around 1920 and worked as professional photographers in Tel Aviv and Haifa. Following an attempt to sell the studio in 1935, it apparently fell to Feitska by default - who maintained it until 1940 . There is no comment about the fate of the studio in the period when Telsiai was under Soviet control prior to the Nazi invasion of June 1941. Feitska, her husband, and two of their children 'went through the horrors of the Telsiai ghetto and became victims of the Nazi Holocaust ... Fortune favored only Rachel (1926-2001), the eldest daughter of Feitska. She survived thanks to the former maid of the Kaplanskis. She took the frightened and confused teenager and looked after her like a mother and in 1945 helped her to leave for Palestine to their relatives. ${ }^{96}$

Although the catalogue treats Chaimas Kaplanskis and his heirs as special and distinctive, it intimates that there exist troves of pictures by similar Jewish photographers whose histories remain to be written. It also tells us a great deal about the practice of photography in an area of Europe that is typically seen as backward in comparison with Central and Western Europe. In this region too, photography was a vital and highly prized part of life, and Jews were at its centre. There were many photographers like the Kaplanskis operating in towns such as Kelme and Jurbarkas. One of the notable things about the family's work, reminiscent of Jacobi 
shooting political figures of every stripe, is the extent to which Jewish photographers were employed to photograph nationalist and religious groups and ceremonies. There was an aspect of the trade, though, that is now seen as bizarre where it is noticed at all, but was apparently something of a Jewish speciality: the photographing of the dead. Photographers who engaged in this often had an unsavoury reputation for taking advantage of the bereaved, as they would use the occasion to entice the family to make reproductions of existing photos. This aspect is not discussed in the catalogue, nor has it been well explained in the history of photography. ${ }^{97}$

Interestingly, but perhaps not surprisingly, photographs of Jews by Jewish photographers, and the work of Jewish photographers generally, in pre-Nazi Europe seem initially to have become highly valued in Germany's photography marketplace. This is evident in the valuations of the photographic collection of Josef Breitenbach, which was first given on loan to, and later bought by, the University of Munich. ${ }^{98}$ In post-war Germany and Austria, beginning in the late $1950 \mathrm{~s}$, some individuals active in photography began to pay attention to the historical eradication of Jews who had been at the heart of, or cutting edge, of the field. Therefore, photojournalists such as Alfred Eisenstaedt, Gisele Freund, Gerti Deutsch, Simon Gutmann, Josef Breitenbach, and Lisl Steiner were 'welcomed' back to Germany and Austria, as was the pioneering collector and historian Helmut Gernsheim. Erich Salomon was posthumously made part of a German cultural canon. All of this served a twofold purpose: it was part of the process of Vergangenheitsbewältigung, and it acted as a means of creating the myth of Weimar Germany, especially Berlin, and pre-World War Two Vienna as precursors to multiculturalism and the greatest incubators of avant-garde trends. The selective appropriation of Jews and photography, as part of Vergangenheitsbewältigung, however laudatory in intent, has been fragmentary and occasionally distorted in historical reflections.

As personalities and as important collectors of historical photography, Helmut Gernsheim and Josef Breitenbach have been integrated into what may be seen as a German discourse on photography. Towards the end of his life, Helmut Gernsheim arranged to sell and donate the 
remaining portion of his collection which was not given to the initial repository of his trove, the University of Texas, to the Reiss-Engelhorn Museum in Mannheim. ${ }^{99}$ While the ReissEngelhorn Gernsheim collection, officially installed in 2002, is certainly impressive, it is not particularly well-treated in the grand scheme of German archives and museums. There is no permanent exhibition space, and the collection, despite a dedicated director, is chronically underfunded and understaffed.

Josef Breitenbach's collection of historical photography, now housed at the University of Munich, which had originally been shown at Munich's municipal museum, is less known and heralded than that of Gernsheim, is on a much smaller scale and not nearly as comprehensive, although it contains a number of fabulous pieces. Breitenbach is mainly remembered as a photographer for his portraits of Bertolt Brecht and Max Ernst and as a teacher of photography of diverse and rather eclectic interests. There seems no doubt, though, that he was invited back to Germany generally, and Munich specifically as a native son in the late 1970s, as an act of restitution. ${ }^{100}$ The first stirrings begin the late 1950s. He was paid well for his 'donation', which he had apparently given on loan to the university before its permanent fate was settled. There were a few grand events, publications, and exhibitions to mark the 'return' of Breitenbach to his home country. As early as 1967, we can see in the light of Breitenbach's efforts to sell off his collection that the works of German Jews and refugees, including Blumenfeld, Eisenstaedt, and Vishniac, were being accorded relatively high value. ${ }^{101}$

To conclude this survey of photography as a Jewish space, we turn to the most artificial yet lethal of Jewish spaces: the Nazi ghettos. There are a number of pictures revealing the persistence or recreation of Jewish photo studios in ghettos. ${ }^{102}$ Photographic equipment was not systematically seized in the Lodz ghetto until 7 November 1941, and remained in use in numerous ghettos for relatively long periods. Although the work produced in ghetto studios obviously constitute 'Holocaust' photographs of victims, we may apply different readings to them: Rather than stressing resilience or defiance in the face of adversity, such photographs 
may be seen as evidence of continuity between Jewish life before the Nazis and that which carried on into the Holocaust. The studios and their patronage were, then, in this view, a piece of 'normal' life, and may even have been largely taken for granted. Just as importantly, and as we have seen in this chapter, photography was crucial to Jews' relations with non-Jews as well as intra-Jewish relationships. A better understanding of photography as Jewish space will help us to comprehend the worlds that Jews and non-Jews made together, as well as to recapture, more sharply, the range of Jewish vocations and identities that were part of their lost world.

\footnotetext{
${ }^{1}$ Michael Berkowitz, "'Jews in Photography': Conceiving a Field in the Papers of Peter Pollack," in Photography \& Culture, Volume 4, Issue 1 (March 2011): 7-28; Berkowitz, "Photography as a Jewish Business: From High Theory, to Studio, to Snapshot," in East
} European Jewish Affairs, Vol. 39, No. 3 (December 2009): 389-400.

${ }^{2}$ In light of Steven Aschheim's pioneering Brothers and Strangers: The East European Jew in German and German Jewish Consciousness 1800-1923 (Madison: University of Wisconsin Press, 1982), and subsequent scholarship by Trude Maurer and others, any consideration of German Jewry must necessarily be cognizant of Ostjuden as ever-present; see also Trude Maurer, Ostjuden in Deutschland, 1918-1933 (Hamburg: H. Christians, 1986).

${ }^{3}$ Barbie Zelizer, ed., Visual Culture and the Holocaust (London: Athlone, 2001).

${ }^{4}$ Michael Berkowitz, The Jewish Self-Image (London: Reaktion, 2000).

${ }^{5}$ For superb analysis of how photography can be conceived as a secular Jewish phenomenmon, see Lisa Silverman, "Reconsidering the margins: Jewishness as an analytical framework," in Journal of Modern Jewish Studies 8.1 (2009): 103-120.

${ }^{6}$ Jeffrey Shandler, "What Does It Mean to be Photographed as a Jew?" Jewish Quarterly Review 94, No. 1 (2004): 8-11. 
${ }^{7}$ David Shneer, Through Soviet Jewish Eyes: Photography, War, and the Holocaust (New Brunswick, NJ: Rutgers University Press, 2011).

${ }^{8}$ Martin Roman Deppner, ed., Die verborgene Spur: Jüdische Wege durch Moderne/The Hidden Trace: Jewish Paths though Modernity (Bramsche: Rasch, 2009); Roman Bezjak and Martin R. Deppner, eds., Jüdisches: Fotografische Betrachungen der Gegenwart in Deutschland (Bielefeld: Nicolai, 2006).

${ }^{9}$ A striking example of this connection is revealed in the film Leaving Home, Coming Home: A Portrait of Robert Frank (dir. Gerald Fox, 2005, for the South Bank Show, LWT).

${ }^{10}$ Nachum (Tim) Gidal, "Jews in photography," in Leo Baeck Institute Year Book 32 (1987): $437-453$.

${ }^{11}$ Ann Stringer and Henry Ries, German Faces (New York: Sloane, 1950).

${ }^{12}$ Henry Ries and Ann Stringer, Deutsche, Gedanken und Gesichter 1948-1949 (Berlin: Argon, 1988).

${ }^{13}$ See Avinoam J. Patt and Michael Berkowitz, "Introduction," in "We Are Here": New Approaches to Jewish Displaced Persons in Postwar Germany, (Detroit: Wayne State University Press, 2010), pp. 1-5.

${ }^{14}$ See, for instance, the interview with Karl Knoebl, a Catholic priest in Mittenwald, in German Faces, p. 52.

${ }^{16}$ Hal Lehrman, "Talking Pictures" (review), in The Saturday Review, October 7, 1950, p. 20; Anne L. Goodman, review of German Faces in The New Republic, 14 August 1950, p. 22; 17 "Henry Reis. Berlin vor 25 Jahren. Fotos aus der Zeit der Berliner Blockade. Ausstellung der Landesbildstelle Berlin vom 18. Mai bis 8. Juli 1973" and "Berlin, Photographien 19461949," 1998.

${ }^{18}$ Henry Ries, Ich war ein Berliner: Erinnerungen eines New Yorker Fotojournalisten (Berlin: Parthas, 2001). 
${ }^{19}$ Michael Berkowitz, Jews and photography in Britain (Austin: University of Texas Press, forthcoming).

${ }^{20}$ Douglas Martin, "Henry Ries, 86, Photographer Who Captured Berlin Airlift," in New York Times, 26 May 2004.

32 Berkowitz, Jews and photography in Britain.

${ }^{33}$ home truths, Boston Chamber of Commerce, May 1944, Vol. V., No. 7, pp. 4-5, in Polaroid Admin Records I.88, "Press clippings-Military Tax, 1944," in Baker Library Historical Collection, Harvard Business School, Boston, MA.

${ }^{34}$ Berkowitz, Jews and photography in Britain.

${ }^{35}$ I. J. Singer, "In der finster," in Perl un andere dertseylungen (Vilne: B. Kletskin, 1929), 7493.

${ }^{36}$ Angnieszka Jagodzińska, "Image and Identity: Warsaw Jews as Others and Non-Others," unpublished paper (2010), University of Wrocław, ${ }^{37}$ Marek Web, "Introduction," in Alter Kacyzne, Poyln: Jewish life in the old country (New York: Henry Holt, 1999), xxi-xxii; Nakhman Blitz, "Der kreyts-weg fun Alter Kacyzne" (The Martrydom of Alter Kacyzne), Dos naye lebn, no. 10, Lodz, 1945.

${ }^{38}$ Israel Biderman ("Isis" or "Izis"), quote in Avraham Tory-Golub, ed., Mariyampol: 'al gedot ha-nahar Sheshupe (Lita) [Mariampole on the River Sheshupe (Lithuania)] (Tel Aviv: Va'ad sefer Maiyampol, 1983), 118, 48-9.

${ }^{40}$ Wilfried Weinke, Verdrängt, vertrieben, aber nicht vergessen. Die Fotografen Emil Bieber, Max Halberstadt, Erich Kastan, Kurt Schallenberg (Weingarten: Kunstverlag Weingarten, 2003); see also Anna Auer and Kunsthalle Wien, Übersee: Flucht und Emigration österreichischer Fotografen 1920-1940/Exodus from Austria: Emigration of Austrian Photographers, 1020-1940 (Wien: Kunsthalle, 1998); Unbelichtet = Unexposed: Muenchner Fotografen im Exil = Munich photographers in exile (Heidelberg: Kehrer, 2010). 
${ }^{41}$ Rolf Sachsse, "'Dieses Atelier ist sofort zu vermieten': Von der 'Entjudung' eines Berufsstandes," "Arieserung" im Nationalsozialismus: Volksgemeinschaft, Raub und Gedächtnis: Jahrbuch 2000 zur Geschichte und Wirkung des Holocaust, Fritz Bauer Institute (Hg.) von Irmtrud Wojak and Peter Hayes (Frankfurt/New York: Campus, 2000), 269-286. ${ }^{42}$ Christine Kühnl-Sager, "Schule Reimann, College of Applied Art" and Heike Stange, "Yva Photographic Studio" in Christoph Kreutzmüller and Kaspar Nürnberg, eds., Final Sale: The End of Jewish Owned Businesses in Nazi Berlin (Berlin: Aktives Museum Faschismus und Widerstand in Berlin and Humboldt-Universität zu Berlin, and New York: Leo Baeck Institute, 2010), 58-51, 68-71.

${ }^{43}$ Christoph Kreutzmüller, Ausverkauf. Die Vernichtung der jüdischen Gewerbetätigkeit in Berlin 1930-1945 (Berlin: Metropol, 2013).

${ }^{44}$ Vienna's Shooting Girls: Jüdische Fotografinnen aus Wien/Jewish Women Photographers from Vienna (Vienna: Jüdisches Museums Wien and IPTS-Institute für Posttayloristische Studien, 2013).

${ }^{45}$ Annette Vonwinckel, "German (Jewish) Photojournalists in Exile: A Story of Networks and Success," German History 31.4 (2013): 453-472.

${ }^{46}$ An identical point about the significance of professional networks among Jews in photography was made in "Jews and Photojournalism: Between Contempt, Intimacy, and Celebrity," in Die PRESSA/The PRESSA: Internationale Presseausstellung Köln 1928 und der jüdische Beitrag zum modernen Journalismus/International Press Exhibition Cologne 1928 and the Jewish Contributions to Modern Journalism, eds. Suzanne Marten-Finnis and Michael Nagel, Band/Volume II(Bremen: Edition Lumiere, 2012), 627-39.

${ }^{47}$ See description of W/W no. 94218, CD no. 0271, Desig no. 634.93, Ferdinand Vitzethum, street scene in Fuerth, United States Holocaust Memorial Museum Photo Archives.

${ }^{48}$ Berkowitz, Jews and photography in Britain. 
${ }^{49}$ Frank Dabba Smith is preparing aPhD dissertation on Leica during the Second World War; see Mark Honigsbaum, "New life through a lens," Financial Times, February 2, 2007.

${ }^{50}$ Wolf Gruner, Jewish Forced Labor Under the Nazis: Economic Needs and Racial Aims (New York: Cambridge University Press), n48, 41.

52 Just how prevalent the Jews in photography were in Vienna is also apparent in its presentday street markets. It takes little effort to find photographs from formerly Jewish studios.

${ }^{53}$ Harvey Fireside, "Delusions and Denials: Viennese Life under the Nazis, ME 1486, Leo Baeck Institute, Center for Jewish History, New York.

${ }^{54}$ Harvey Fireside, "Delusions and Denials: Viennese Life under the Nazis, ME 1486, Leo Baeck Institute, Center for Jewish History, New York.

${ }^{55}$ Gordon Horwitz, In the Shadow of Death: Living Outside the Gates of Mauthausen (New York: Free Press, 1990), 8-22.

${ }^{56}$ Christian Dürr, Archiv der KZ-Gedenkstätte Mauthausen, e-mail with the author, $18 / 07 / 2013$

${ }^{57}$ Card file data set, Archiv der KZ-Gedenkstätte Mauthausen, Minoritenplatz 9, 1014 Wien. 58 The photographer from Mauthausen who has received most acclaim is Francisco Boix, a prisoner captured in the Spanish Civil War; see Benito Bermejo, Francisco Boix, der Fotograf von Mauthausen, Mauthausen-Studien special issue (Vienna: Mandelbaum, 2007).

${ }^{59}$ Card file data set, Archiv der KZ-Gedenkstätte Mauthausen, Minoritenplatz 9, 1014 Wien.

${ }^{60}$ Bernard Gotfryd, Anton the Dove Fancier And Other Tales of the Holocaust (New York: Washington Square Press, 1990); Bernard Gotfryrd, The Intimate Eye (New York: Riverside, 2006); Bernard Gotfryd, Widuje ich w snach. Nowe opowiadania/I Can See Them in My

Dreams: The New Stories [Polish and English], ed., Krystyna Kasinska, trans. Jaroslaw Wlodarczyk (Radom: Miejska Biblioteka Publiczna w Radomiu, 2008).

62 Ibid. 
${ }^{63}$ Gotfryd, Anton the Dove Fancier, 65.

${ }^{64}$ Bernard Gotfryd, interview with the author, Forrest Hills, New York, 28 June 2013.

${ }^{65}$ Ibid.

${ }^{66}$ Gotfryd, Anton the Dove Fancier, 53-4.

${ }^{67}$ Gotfryd, Anton the Dove Fancier, 61-7.

${ }^{68}$ Gotfryd, Anton the Dove Fancier, 62-3.

${ }^{69}$ Gotfryd, Anton the Dove Fancier, 68.

${ }^{70}$ Gotfryd, Anton the Dove Fancier, 71.

${ }^{71}$ Ibid.

${ }^{72}$ Gotfryd, Anton the Dove Fancier, 75.

${ }^{73}$ Bernard Gotfryd, interview.

${ }^{74}$ Michael Berkowitz, The Crime of My Very Existence: Nazism and the Myth of Jewish Criminality (Berkeley: University of California Press, 2007), 42-3.

${ }^{75}$ Photograph of Paul Fuchs, in Sebastian Piatkowski and Arkadiusz Kutkowski, "Distrikt Radom": Polityka okupacyjnych wladz niemieckich wobec lucnosci polskiej w dystrykcie radomskim [exhibition, available online], at http://ipn.gov.pl/_data/assets/pdf_file/0010/58519/1-19637.pdf [accessed December 2014]; "Postwar, War criminal Dr Herbert Boettcher, Item 57530, Yad Vashem Photo Archive, available at http://collections.yadvashem.org/photosarchive/en-us/61552.html [accessed December 2014]; https://www.google.com/culturalinstitute/asset-viewer/galicia-poland-fritzkatzmann-commander-of-the-ss-and-the-police-in-the-galicia-district-meeting-heinrichhimmler/ZwHM14fhfgQ2fA?hl=en [accessed December 2014]; http://www.dwsxip.pl/reich/biografie/lista2/3065.html [accessed December 2014]; 
commons.wikimedia.org/wiki/File:Pierre_Laval_and_Carl_Oberg_in_Paris.png. [accessed December 2014]; http://www.deathcamps.org/reinhard/krueger.html [accessed December 2014].

${ }^{76}$ Berkowitz, Crime of My Very Existence, 74-111.

${ }^{77}$ Marion Levenson Ross, "Lotte Jacobi 1896-1990," in Jewish Women's Archive, available at http://jwa.org/encyclopedia/article/jacobi-lotte [accessed December 2014].

${ }^{78}$ Sandra S. Phillips, "An interview with Lotte Jacobi," CENTER Quarterly [Catskill Center for Photography], Vol. 3, No. 1 (1981) (unpaginated).

${ }^{79}$ Heike Stange, "Yva Photographic Studio," in Final Sale, 68-71; Anna Zika, "Dahinter steckte ein kluger Kopf. Else Neulaender-Simon," in The Jewish Engagement in Photography, eds. Martin Deppner and Michael Berkowitz (Oldenburg: Carl von Ossietzsky Press, forthcoming).

${ }^{80}$ Berkowitz, Jews and photography in Britain.

81 "Leo Rosenthal, Photographer at U.N. for 24 Years, Is Dead," in New York Times, October 29, 1969.

${ }^{82}$ Leo Rosenthal. Ein Chronist in der Weimarer Republik. Fotografien 1926-1933.

Eds. Landesarchiv Berlin and Rechtsanwaltskammer Berlin. With text by Bianca WelzingBräutigam, Janos Frecot and Bernd Weise (Berlin and München: Shirmer/Mosel, 2011).

${ }^{83}$ Ibid., 17.

${ }^{84}$ Ibid., $17-8$.

${ }^{85}$ Ibid., 19.

${ }^{86}$ Ibid., 13.

${ }^{89}$ Ibid., 18-20.

${ }^{90}$ Ibid., 28.

${ }^{91}$ Ibid., 8 . 
${ }^{92}$ Berkowitz, Jews and photography in Britain.

${ }^{93}$ Fotografas/Photographer Chaimas Kaplanskis, Fotoalbumas-Katalogas/Photoalbum-

Catalogue, Vakaru Lietuva XIX a. pab.-XX aa. Vid., Western Lithuania $19^{\text {th }}-20^{\text {th }}$ c. (TelsiasVilnius: Vilniaus dailes akademijos leidykla, 2007).

${ }^{94}$ Marina Petrauskiene, "On the Path of the Photographer," in Fotografas/Photographer Chaimas Kaplanskis, 42, 54.

${ }^{95}$ Ibid., 47.

${ }^{96}$ Ibid., 49.

${ }^{97}$ Berkowitz, Jews and photography in Britain.

${ }^{98}$ Evaluation from Münchner Stadtmuseum, ca 1967, appraisal of Josef Breitenbach photographic collection, AG 90: 5/16, Center for Creative Photography, University of Arizona, Tucson, Arizona.

${ }^{99}$ Berkowitz, Jews and photography in Britain.

${ }^{100}$ Jürgen Kobe to Josef Breitenbach, 15.6.1978, AG 90 3/3, Center for Creative Photography, University of Arizona, Tucson, Arizona.

${ }^{101}$ Evaluation from Münchner Stadtmuseum, ca 1967, appraisal of Josef Breitenbach photographic collection, AG 90: 5/16, Center for Creative Photography, University of Arizona, Tucson, Arizona.

102 'Studio portrait of two Jewish girls in the Bedzin ghetto. Pictured are Maniusia Gipsman (left) and her cousin, Dina. Both girls perished in Auschwitz. Maniusia was 13 years old at the time of her death,' USHMM, available at:

http://digitalassets.ushmm.org/photoarchives/detail.aspx?id=1089263 [accessed December 2014]; 'Studio portrait of Rozia Merin wearing a Jewish badge in the Bedzin ghetto,' USHMM, available at: 
2014]. 